\title{
El impulso nacionalizador de la Revolución de 1868
}

L'élan nationalisateur de la Révolution de 1868

The Nationalizing Impulse of the Revolution of 1868

José Álvarez Junco y Gregorio de la Fuente Monge

\section{OpenEdition}

\section{Journals}

Edición electrónica

URL: http://journals.openedition.org/bhce/1637

DOI: $10.4000 /$ bhce. 1637

ISSN: 1968-3723

Editor

Presses Universitaires de Provence

Referencia electrónica

José Álvarez Junco y Gregorio de la Fuente Monge, « El impulso nacionalizador de la Revolución de 1868 », Bulletin d'Histoire Contemporaine de l'Espagne [En línea], 55 | 2020, Publicado el 01 septiembre 2020, consultado el 28 noviembre 2020. URL : http://journals.openedition.org/bhce/1637 ; DOI : https://doi.org/10.4000/bhce.1637

Este documento fue generado automáticamente el 28 noviembre 2020

Bulletin d'histoire contemporaine de l'Espagne 


\title{
El impulso nacionalizador de la Revolución de 1868
}

\author{
L'élan nationalisateur de la Révolution de 1868 \\ The Nationalizing Impulse of the Revolution of 1868 \\ José Álvarez Junco y Gregorio de la Fuente Monge
}

\section{Introducción}

1 El conflictivo período político desarrollado entre 1868 y 1874 cerró el ciclo de las revoluciones liberales decimonónicas españolas que habían abierto sesenta años antes las Cortes de Cádiz, reunidas para llenar el vacío de poder provocado por la invasión napoleónica. Los radicales cambios legislativos aprobados por aquellos liberales gaditanos se hicieron en nombre de la nación, nuevo ente que desplazó al monarca absoluto como detentador de la soberanía. Ahí residió la gran novedad inicial del proceso : la aparición de la nación como legitimadora del paso de la monarquía de derecho divino a un sistema de poder limitado y representativo.

Pero esta primera fase liberal se solapó en el tiempo con la independencia de la mayoría de los territorios americanos hasta entonces pertenecientes a la monarquía española, lo cual obligó a una radical remodelación de aquella estructura de poder, que pasó de ser un imperio transoceánico a un Estado europeo con limitados restos coloniales. De la anterior monarquía imperial no podían seguir ahora en pie ni su sistema fiscal ni su organización institucional, territorial o administrativa. El Estado, como la nación en la que se apoyaba, tenía que nacer de nuevo. Lo cual originó un círculo vicioso propio de situaciones postcoloniales, porque ambos, Estado y nación, necesitaban apoyarse mutuamente: el primero precisaba de la segunda como referencia identitaria generadora de unos sentimientos de pertenencia a una comunidad que legitimaba su acción de gobierno ; y la segunda del primero como difusor de su imagen y su atractivo político entre los ciudadanos a través de un sistema escolar, un servicio militar, unas instituciones culturales y unos espacios públicos cargados de simbolismo. Al 
encontrarse ambos en una fase temprana de su construcción, los dos se vieron perjudicados por la debilidad del otro.

3 Si a ello se añade la crónica y casi espasmódica inestabilidad política de los dos primeros tercios del XIX, se comprende que, al iniciarse la Gloriosa, el proceso nacionalizador no se hubiese desarrollado aún con fuerza. Pensándolo con distancia, y en términos europeos, su atraso no era excepcional, pues el Sexenio coincidió con la culminación de los procesos de unificación alemana e italiana y con el inicio de la III República, el gran régimen nacionalizador en Francia. Pero, en el caso español, no existió ningún movimiento político-cultural de fuerza y unanimidad comparables al Risorgimento italiano, al clima nacionalista bismarckiano o al republicanismo, laico e igualitario francés. Los sesentayochistas intentaron precisamente cubrir ese vacío, desempeñar el papel de la III República vecina. Los discursos que acompañaron el destronamiento de Isabel II fueron, tanto en el campo como en las ciudades, esencialmente patrióticos. Era el pueblo español quien había expulsado a los Borbones ; la revolución era producto de la voluntad de la nación.

El problema era que la nación, en España, estaba siendo construida en dos versiones distintas e incluso enfrentadas. La primera, nacida en Cádiz, era la liberal. Según ella, el pueblo español existía desde hacía milenios y siempre había defendido celosamente tanto su independencia frente a poderes exteriores como su libertad política interna. Lo habrían demostrado, en su idealizada plenitud medieval, el Fuero Juzgo, los concilios visigodos, las Cortes y fueros municipales de la Reconquista. La excepción habrían sido los trescientos años de tiranía inaugurados por la dinastía extranjera de los Habsburgo, y continuados por los Borbones, que las Cortes gaditanas declararon estar clausurando. El pueblo español pasaba, pues, de estar encadenado a emancipado, lo cual no era, desde luego, una innovación moderna, sino un retorno a la normalidad, a su forma natural de ser. Así lo habían dicho los revolucionarios gaditanos y así lo pensaban sus sucesores de 1868.

5 La otra versión del mito nacional, la católico-conservadora, estaba más atrasada en su elaboración, pues había surgido en tiempos de Isabel II alrededor del grupo de los neocatólicos y, probablemente, apenas había penetrado aún en los medios rurales. Su núcleo doctrinal era sencillo : el ser de España se articulaba alrededor de la monarquía y, más aún, de la religión; el apogeo de la nación había coincidido con su defensa inquebrantable del catolicismo, frente a turcos y protestantes, y su decadencia se había debido al alejamiento de aquellos principios al haberse dejado seducir por novedades foráneas.

6 Los neos, sin embargo, aterrorizados ante los acontecimientos revolucionarios, tendieron a integrarse en el carlismo al iniciarse el Sexenio. Pero ello no hizo que se alejaran del nacionalismo, sino que, al revés, incorporaran la nación, el nuevo mito legitimador del poder, al ideario carlista, antes asociado exclusivamente a los valores, creencias, jerarquías e instituciones del Antiguo Régimen ${ }^{1}$. Los años de la Gloriosa coincidieron también con otro acontecimiento revolucionario de gran impacto, la Comuna de París, frente a la cual el conservadurismo europeo reaccionó añadiendo el patriotismo a sus clásicos valores de familia, religión, jerarquía o propiedad. Ante el nuevo espectro que recorría Europa, el internacionalismo obrero, los defensores del orden establecido incluyeron la adhesión a la nación entre los pilares básicos de las sociedades civilizadas ${ }^{2}$. 
7 Prueba de lo que decimos son algunos títulos de la prensa carlista del Sexenio Democrático : La Monarquía Nacional (Vich), La Nacionalidad (Orense), El Eco de Numancia (Soria), El Eco de Viriato (Zamora), La Reconquista (Madrid) o La Bandera Nacional (Cuenca), cabeceras que indican que la apropiación del lenguaje y del historicismo nacionalista estaba ya avanzado, sobre todo si se comparan con los títulos de los años treinta y cuarenta (El Amigo de la Religión, El Realista, El Genio del Cristianismo, La Voz del Católico, La (ruz). En el mismo sentido debe interpretarse la presentación que un periódico barcelonés de esta ideología, El Nuevo Pelayo, hacía de don Carlos como el caudillo de la moderna "Reconquista », que había dado "el grito de libertad" y estaba llamado a restaurar "la nación " en su unidad católica y plenitud histórica venciendo a "las bandas liberales ", los nuevos herejes de España ${ }^{3}$. La escisión de 1888 demostraría que este proceso estaba suficientemente afianzado como para relegar a situación minoritaria a los integristas, aún prenacionales.

Que el proceso nacionalizador estaba en marcha y que el Sexenio lo impulsó con fuerza se demuestra también por el amplio uso del término “nacional » para referirse a la comunidad política española. En el discurso liberal de aquellos años este adjetivo se aplicó tanto a conceptos (libertad, voluntad, unidad, historia, honor, gloria, todos ellos "nacionales ») como a instituciones (teatro, milicia, imprenta, museo; " nacionales" también todos) e incluso a empresas, asociaciones o negocios privados (Café Nacional, Fomento de la Producción Nacional, compañía de seguros La Nacional ${ }^{4}$ ). Se puso igualmente de moda llamar " nacional» a lo que se consideraba " nuestro » : industria nacional, fiesta nacional, Episodios Nacionales. La propia Revolución septembrina se autocalificó, en muchas ocasiones, de " alzamiento nacional ".

Cierto que los múltiples conflictos políticos que caracterizaron los años del Sexenio no pudieron plantearse en términos nacionales. Para empezar, porque se trató de problemas internos, que no cuestionaron la idea de España ni su unidad: carlistas, o republicanos, luchaban por la religión, el rey, los fueros, la república, la democracia, la federación; no luchaban por o contra "España ». Ni siquiera el catalanismo, que acabaría siendo uno de los más graves de esos conflictos internos, estaba en ese momento enarbolando un proyecto nacional alternativo al español; la Cataluña de la Renaixença era la patria, una comunidad cultural perfectamente compatible con España como nación política. En cuanto a las guerras internacionales, no las hubo (algún momento grave, que rozó el peligro bélico, como el caso Virginius, no llegó a provocar movilizaciones ciudadanas). La única excepción sería la guerra de Cuba, planteada por los independentistas como de afirmación nacional frente a España; pero desde la Península tampoco se vio en esos términos -la nación frente a un poder foráneo-, sino como un intento de secesión de una provincia ultramarina promovido por una minoría antipatriota vendida a los intereses estadounidenses.

10 No había, pues, en principio, obstáculos para el impulso nacionalizador emprendido por los revolucionarios. Los problemas, sin embargo, surgieron desde el interior del propio proyecto político, porque la nación que los liberales querían construir estaba demasiado ligada a su identidad y a su programa político como opción partidista. Piénsese simplemente en los personajes exaltados como héroes o modelos patrióticos : Riego, Espartero, Torrijos, Mariana Pineda (o el propio Prim, tras su muerte), los enemigos del absolutismo o del carlismo. De la identidad nacional propuesta quedaba excluido lo católico-monárquico. 
11 Un segundo problema fueron las divergencias internas de la propia familia liberal, que eran antiguas, pero que ahora se estaban ahondando y reformulando ${ }^{5}$. El enfrentamiento no era ya sólo entre moderados y exaltados : lo era entre monárquicos y republicanos, y aun entre las distintas fracciones de unos y otros; y tampoco se limitaba al terreno dialéctico, sino que se elevaba con frecuencia al enfrentamiento armado.

12 Seguía, eso sí, habiendo muchas coincidencias básicas entre ellos. Y, de momento, en los primeros meses del Sexenio, esas coincidencias permitieron poner en marcha una tarea nacionalizadora que presentaba un mínimo de rasgos aceptables para todos.

\section{Elementos nacionalizadores comunes al proyecto revolucionario liberal}

La primera idea compartida por los diversos proyectos liberales de " regeneración nacional » era la exaltación de la nación libre y soberana, que debía recuperar su lugar propio entre las grandes potencias europeas. Lo cual requería modernizarla políticamente, reforzar el Estado, abrirlo a la participación ciudadana e independizarlo de poderes ajenos (como la Iglesia romana) ${ }^{6}$.

14 Legitimada por apelaciones a la libertad, al pueblo y a la soberanía nacional, la Gloriosa fue, como sabemos, un movimiento antidinástico, pero no necesariamente antimonárquico. Los Borbones, entregados al clericalismo ultramontano y adictos a un poder que anulaba la voluntad popular -o nacional-, eran los enemigos no sólo de la libertad, sino de la nación. Estaban “ divorciados de la nación », a la que no concebían sino como un patrimonio familiar ; eran la " raza maldita ", los " enemigos del pueblo ». Y dado que este pueblo, el español, era el único dueño legítimo de la soberanía, son lógicos los tres jamases de Prim ante la posibilidad de retorno de algún miembro de aquella familia al trono. Un progresista catalán, como Víctor Balaguer, aprovecharía la ocasión para remontar el repudio de la dinastía a su inaugurador, Felipe V, por haber abolido los fueros aragoneses, culminación de la obra absolutista y centralizadora de los Habsburgo. Los progresistas, que eran mayoría entre los monárquicos revolucionarios, condenaron de esta manera a los Borbones en bloque, y sus diferencias con los republicanos fueron, en este terreno, poco relevantes. El principio de la soberanía nacional era para ambos el pilar regenerador de la vida política? ${ }^{7}$

La fiesta revolucionaria del otoño de 1868 manifestó bien el sentido del cambio político al acompañarlo de una destrucción generalizada de las imágenes y símbolos que representaban a Isabel II y toda su dinastía. La inicial, cifra y corona de la reina fue arrancada de las paredes y los uniformes militares; sus escudos de armas, rotos y recortados de las banderas; los rótulos de calles, cafés, teatros y cabeceras de periódicos que evocaban a la caída dinastía, arrancados y sustituidos por otros referidos a los caudillos y lemas de la revolución; la Ciudadela, en Barcelona, epítome de la tiránica opresión iniciada en 1714, demolida.

Los símbolos desaparecidos fueron sustituidos por otros cargados de significado liberal. Por las calles se exhibieron retratos de Prim y, sobre todo, de Espartero, "la más genuina representación de la Soberanía Nacional ». Los estandartes y banderas de la antigua Milicia Nacional añadieron lemas o inscripciones como "Soberanía Nacional » o “Viva la Libertad». Se plantaron “árboles de la libertad» y se utilizaron cintas, 
adornos de pelo y corbatas de colores, en especial el morado, referidos a gestas revolucionarias o a glorias antiguas como los Comuneros de Castilla. Los sellos de correos, con la efigie de Isabel II, fueron estampillados con la sobrecarga de " Habilitado por la Nación " y la Junta de Segovia acunó una moneda con los lemas "Soberanía Nacional - España Libre» y “ 29 de Septiembre de 1868 " (fecha del triunfo de la revolución en Madrid, que provocó el exilio de la reina a Francia). La Marcha Real dejó su lugar, de la noche a la mañana, al Himno de Riego y, en menor medida, a La Marsellesa o los himnos Garibaldi y Luchana. Se compusieron también algunos himnos nuevos, como ¡Abajo los Borbones!, con letra de Antonio García Gutiérrez y música de Emilio Arrieta, y iViva la libertad!, de Ángel Mondéjar y Manuel Fernández Carvajal. En cuanto a las obras de teatro estrenadas al calor de la revolución, para saludar a la España libre ya de Isabel II, baste con recordar algunos títulos: ¡Abajo los Borbones!, La Soberanía Nacional, ¡España Libre! o La Redención de la Patria ${ }^{8}$.

El mitologema nacionalista, procedente del inicio del siglo y común a todos los liberales, se mantuvo sin cambios. Salvo en el nombre, pues la tradición que hasta entonces se había llamado liberal pasó a titularse democrática. Todos coincidían, eso sí, en que España era una comunidad humana natural, asentada en la Península Ibérica desde tiempos inmemoriales, tan dotada de hábitos de autogobierno y celosa de su independencia y libertad que siempre se había opuesto tanto a invasiones extranjeras como a tiranías interiores. Monárquicos y republicanos mitificaban por igual la gloriosa época medieval, caracterizada por los fueros municipales, las Cortes representativas y la convivencia de tres culturas, de la que sólo había salido el país al ser derrotados los Comuneros castellanos en Villalar. El absolutismo posterior se habría debido a la imposición de una dinastía extranjera, que había atropellado las libertades y expulsado a las minorías religiosas; lo cual había originado, inevitablemente, la decadencia nacional. Y el resurgimiento se había iniciado con la sublevación antinapoleónica de 1808 , impulsada por el amor a la libertad y la independencia nacional y dirigida contra el despotismo monárquico tanto como contra la agresión extranjera.

En esta interesada versión del pasado, las diferencias entre monárquicos y republicanos eran escasas, pero no inexistentes. Por ejemplo, los republicanos tendían a resaltar las peculiaridades de los antiguos reinos, más adecuados a su proyecto federal, mientras que los monárquicos subrayaban lo que esos reinos tenían en común, que eran unas instituciones políticas limitadoras del poder real. Una segunda diferencia era que la salida del paraíso medieval se atribuía por los monárquicos a una dinastía extranjera, mientras que para los republicanos se debía a una institución extranjera, la monarquía, cualquiera que fuera la familia en que encarnara. Y había una tercera y última diferencia, de grado, en esta atribución de culpas por la decadencia nacional : los monárquicos la anclaban en el sector inquisitorial e intolerante del clero; los republicanos, en cambio, condenaban a la Iglesia en su conjunto, institución extranjera, enemiga del pueblo español y dominada por el papa-rey de Roma.

La coincidencia, sin embargo, era completa en la conexión entre la historia nacional y la situación revolucionaria : el Sexenio, al igual que las Cortes de Cádiz sesenta años antes, quería restaurar las libertades abolidas en 1521 y reanudar la historia de una nación que en esencia, como había demostrado tantas veces en el pasado, era libre y tolerantes. 


\section{La monarquía democrática (1869-73)}

Las elecciones celebradas en 1869 otorgaron la mayoría a los monárquicos, en ese momento sin rey, y Prim se convirtió en el árbitro de la situación. La élite monárquicorevolucionaria demostró su cohesión al elaborar la Constitución en sólo cuatro meses (a diferencia de la incapacidad republicana, pocos años más tarde, para llegar a un acuerdo), y en su rápida y victoriosa respuesta militar a las sublevaciones carlista y republicana (no así a los cubanos, igualmente alzados en armas) ${ }^{10}$.

Los principales rasgos de la Constitución aprobada en 1869 demuestran la ambición y profundidad del proyecto revolucionario. Se consagraba en ella la monarquía, pero una monarquía de nuevo cuño, pues su fundamento era democrático. La corona era un poder público, derivado de la voluntad popular, que simbolizaba la unidad nacional y la continuidad histórica, a la vez que garantizaba la consolidación de las conquistas revolucionarias. Esta forma de régimen, propia de la mayoría de los países europeos avanzados, aunaba progreso y orden, libertad y tradición.

22 En la búsqueda de candidatos para el trono español, desarrollada en un complejo proceso entre 1869 y 1870, una de las opciones fue el general Espartero, cuya elección, como argüían sus partidarios, hubiera sido mera cuestión interna y excluido la intervención de potencias exteriores. Fue un potente argumento nacional, aunque no resultara decisivo en el debate.

3 Descartada la candidatura liberal de Espartero, la búsqueda de un rey no español estuvo muy condicionada por la situación internacional, lo cual jugó en contra de la imagen revolucionaria de una nación soberana, libre e independiente. En la Europa de las unificaciones nacionales, el candidato regio ideal para el proyecto nacionalista español era el portugués, que permitía pensar en una futura Unión Ibérica. Pero Fernando de Coburgo rechazó la oferta, en un momento en el que, además, el republicanismo portugués estaba evolucionando hacia una idealización antiespañola de los “ restauradores » de 1640. Lo cual puso punto final al sueño paniberista.

En el otoño de 1870, en un momento de gran tensión entre las potencias europeas, se impuso la opción de Amadeo de Saboya. El hecho de que las Cortes le eligieran ratificó, indiscutiblemente, la supremacía de nación sobre el monarca, y evocó la revolución inglesa de 1688, la "Gloriosa » con la que la española de 1868 pretendía compararse.

El texto constitucional era novedoso en la tradición española, al iniciarse con el enunciado de los derechos y libertades individuales. Todos los ciudadanos, como miembros de la nación, quedaban igualados en derechos y capacidad para tomar parte en las decisiones colectivas. Lo cual debe interpretarse, de nuevo, como un refuerzo de la idea nacional. En cuanto a la organización institucional, las dos Cámaras eran electivas y el parlamento, en el funcionamiento político normal, primaba sobre el ejecutivo. Las Cortes elaboraban las leyes y otorgaban su confianza al Gobierno. Pero no debe olvidarse que la confianza exigida era doble, pues para la formación del Gobierno se exigía también la aquiescencia regia ; no así para la sanción de las leyes, ya que, por primera vez en la historia constitucional española, no existía el veto regio.

Otras medidas nacionalizadoras impulsadas por los monárquicos se relacionaron sobre todo con la secularización del espacio público. No proclamaron la separación de la Iglesia y el Estado, pero redujeron los privilegios del clero y lo sometieron al poder civil. Para los revolucionarios, el clero -vaticanista, intolerante y fanático- era el 
principal “enemigo de la civilización, el progreso y la libertad». De ahí, el reconocimiento de la libertad de cultos, bajo una redacción alambicada y tímida pero que en definitiva supuso la mayor ruptura con la tradición constitucional previa, pues terminaba con la "unidad católica", núcleo de la identidad nacional para conservadores y carlistas. Se obligó también al clero, como a todos los empleados públicos, a jurar la Constitución, medida que sin embargo apenas pudo llevarse a la práctica, pues los eclesiásticos prefirieron perder sus haberes antes que doblegarse ante una ley que consideraban atea. Con las leyes de registro y matrimonio civiles y el decreto sobre entierros no católicos en cementerios municipales, el Estado invadió y secularizó, además, espacios reservados hasta entonces a la Iglesia. Todo este conjunto de medidas, no muy radicales en sí mismas, suponían traumáticas innovaciones en una sociedad tan arraigadamente católica como la española, y lanzaron a la Iglesia en brazos de los enemigos de la Revolución, algo que justificaron como defensa de la nación española, asociada para ellos de manera indisoluble a la unidad católica de España.

Estas disposiciones constitucionales completaron las medidas previamente tomadas por el Gobierno Provisional, que habían sido desde el primer momento muy radicales: reconocimiento de las libertades de expresión, imprenta, teatro y cátedra; reorganización laicista de la enseñanza, con la desaparición de facultades de Teología y las subvenciones a seminarios; supresión de la Compañía de Jesús y de todos los monasterios y casas de religiosos fundados después de 1837 ; reducción a la mitad de los conventos subsistentes, excepto los dedicados a la beneficencia y enseñanza; disolución de las conferencias de San Vicente de Paul ; nacionalización de bibliotecas, archivos y objetos artístico-culturales eclesiásticos; y diversas incautaciones de edificios religiosos ${ }^{11}$.

Desde el lado positivo, los revolucionarios monárquicos, de los que estamos tratando ahora, mostraron escasa voluntad de utilizar el servicio militar y la escuela como instrumentos para nacionalizar a niños y jóvenes españoles. En el primer caso, se encontraron con insuperables dificultades derivadas del problema de las quintas, la célebre "contribución de sangre" que habían prometido suprimir, cosa que no pudieron hacer al sobrevenir la guerra de Cuba. En 1870, Prim se vio obligado a admitir la redención colectiva de quintos por parte de ayuntamientos y diputaciones. Lo que, en definitiva, imposibilitó la universalización del servicio militar obligatorio. En relación con este tema, cabe incluso recordar -aunque no queremos entrar ahora en el período republicano- que fue la Asamblea Nacional de 1873, de mayoría monárquica progresista, la que abolió las quintas ${ }^{12}$.

29 Algo parecido ocurrió con la escuela pública, el otro gran canal nacionalizador, como arma inculcadora de sentimientos de identidad colectiva en los niños. Al triunfar la revolución fue abolida la reciente ley de Instrucción Primaria neocatólica, de junio de 1868, que cedía el control de la escuela al clero, y se restauró la ley Moyano de 1857 . Se estableció como principio general la libertad de enseñanza y de establecimiento de centros educativos, y los niveles medio y universitario fueron reformados en sentido liberal y abiertos a la educación femenina, aunque en este último terreno el impacto fue limitado.

30 En cuanto a la educación primaria, el ministro Ruiz Zorrilla estableció en octubre de 1868 la más amplia libertad. Incluso consideró como “ideal al que debemos aproximarnos [...] la supresión de la enseñanza pública», dados los errores a los que 
conducía la existencia de una verdad oficial. Ante la imposibilidad de alcanzar tal ideal, el Estado, sin embargo, reconocía la necesidad de desempeñar un papel subsidiario, apoyando las iniciativas particulares y los poderes locales. A partir de estas premisas, y en cumplimiento de la Ley Moyano, la enseñanza primaria pública siguió siendo financiada por los municipios, obligatoria únicamente para los niños de seis a nueve años y sin una asignatura de Geografía e Historia, que se reservaba para las minoritarias escuelas "superiores". Las primarias " elementales", predominantes en el medio rural y únicas gratuitas para pobres, no fueron así instrumentos eficaces para inculcar la identidad nacional entre la inmensa mayoría de la población. En 1870 se tomó una disposición laicista, al eximir de enseñanza religiosa a los niños cuyos padres lo solicitaran. Pero no se alcanzó el objetivo de crear una escuela pública laica, general, obligatoria y gratuita, como haría poco después la III República francesa, régimen nacionalizador por excelencia ${ }^{13}$.

\section{Símbolos nacionales}

31 Al crear la nueva unidad monetaria, la peseta, el Gobierno Provisional solicitó un informe a la Academia de la Historia sobre la imagen simbólica de la nación española y el escudo de España que debían figurar en las monedas. Para lo primero se optó por una figura femenina de Hispania de la época de Adriano, una " matrona recostada en los Pirineos, rodeada del Océano, con los pies en el Estrecho, una rama de oliva en la mano y una diadema en la cabeza ». En cuanto al escudo, se reformó el antiguo de la monarquía en su versión abreviada : se eliminó el escudete central de los Borbones, se sustituyó la corona real de la parte superior por otra mural o almenada, se añadieron las armas de Aragón y Navarra a las de Castilla, León y Granada, y se dejaron, en cambio, invariables las columnas de Hércules que lo flanqueaban. En conjunto, esta representación territorial referida a los antiguos reinos se asemejaba a la diseñada por los afrancesados para José $\mathrm{I}^{14}$.

Dicha alegoría femenina de España apareció en las monedas acuñadas en 1869 y 1870, que representaban en su reverso el nuevo escudo; sin corona en las de cobre, con corona mural en las de plata y con corona real en las de oro. En las monedas de mayor circulación, las fraccionarias de cobre, el escudo lo sostenía un león. En las de oro y plata aparecía, por primera vez en la historia de la numismática, la leyenda “ España » abandonándose así las anteriores expresiones “de España y las Indias » o “ de las Españas »- ; y las dos monedas de mayor valor, de 5 y 100 pesetas, llevaban grabada en el canto la leyenda "Soberanía Nacional ». La Constitución de 1869 ordenaba, en cambio, poner el busto y el nombre del monarca en las monedas, medida que se aplicó en el reinado de Amadeo : la alegoría de España fue sustituida por el busto del rey -con la leyenda "Amadeo I, rey de España »- y la corona mural del escudo por la real, añadiéndose a este último en su parte central la dinástica cruz de Saboya. Estas modificaciones aparecieron en la nueva serie numismática de 1871, en que se acuñaron piezas de plata y oro, pero no nuevas de cobre, por lo que paradójicamente las monedas más usadas y populares fueron las de los años anteriores : las perras (en que terminó degradando los leones el lenguaje popular), siendo, por el contrario, muy poco vistos los amadeos, o duros de plata, por lo que la monarquía democrática desaprovechó este medio de socialización política ${ }^{15}$. 

dedicaron a personajes históricos, en la primera emisión a Gutenberg y en la segunda y última, a tres españoles : el Gran Capitán, Hernán Cortés y Cristóbal Colón. Este tipo de motivo era la primera vez que se utilizaba en España y, aunque no figurasen los nombres, los retratados eran hasta cierto punto reconocibles ${ }^{16} \mathrm{y}$ evocaban las glorias nacionales de la época imperial, muy apreciadas por todos los grupos políticos para el caso de las americanas pero no así para el de las europeas, habitualmente criticadas por el liberalismo radical $^{17}$.

Sobre los sellos de correo realizados por la Fábrica Nacional, en el único emitido en el periodo de interinidad (1870) figuraba una cabeza de mujer con corona mural, efigie alegórica de España. Pero en el reinado de Amadeo se volvió a la simbología tradicional : el busto del monarca o la corona real. No obstante, a diferencia de Isabel II, en uno de los sellos de 1872 el nuevo rey aparecía con la cara girada al frente y con hombros que permitían imaginar el cuerpo, lo que humanizaba la imagen del jefe de Estado elegido por los representantes de la nación y le alejaba de la sacralidad de la numismática clásica (cabeza lateral recortada por el cuello) ${ }^{18}$.

tas publicaciones de la Imprenta Nacional, el mismo 30 de septiembre, día siguiente al del triunfo revolucionario, la Gaceta de Madrid sustituyó el escudo de armas de los Borbones de su encabezamiento por una improvisada alegoría femenina de la nación con la balanza de la justicia y el caduceo -vara con dos culebras, atributo de Mercurio, que simbolizaba la paz y el comercio entre las naciones-, acompañada de un gallo (símbolo de la libertad) y un león (el pueblo), que pisaba un perro (la tiranía). Esta nueva imagen fue impuesta por la Junta revolucionaria de Madrid, de mayoría monárquica, y terminó encabezando también algunos boletines oficiales de otras juntas revolucionarias provinciales. En realidad, se trataba de una antigua alegoría de la Justicia, sin connotación política alguna, que había sido utilizada en los años cuarenta en el mundo de la abogacía, pero que, veintitantos años después, sirvió para representar a la nación española encumbrada por la revolución de 1868. La reutilización política de dicha alegoría fue más efectiva cuando se acompañó de los lemas de la revolución, como en el caso del Boletín de la Junta de Logroño ${ }^{19}$.

Desde 1869, el encabezamiento de la Gaceta llevó una figura femenina sedente, con diadema laureada, apoyada en el escudo de España (desprovisto de toda corona y con el tradicional cuartelado castellano-leonés), acompañada del león (sin gallo) y sujetando un libro (la Constitución, que se aprobaría ese año). Por fin, en 1870 se puso el nuevo escudo de España, con corona mural y las columnas herculinas con la leyenda plus ultra, al frente del periódico oficial del Estado. El mismo se mantuvo al inicio del reinado de Amadeo I, pero el 9 de marzo de 1871 se volvió al tradicional escudo castellano-leonés, con dos cambios : la sustitución de la corona almenada por la real y el añadido de la cruz de Saboya. Por último, conservando estas dos modificaciones, en septiembre de 1872, y hasta la proclamación de la República, reapareció el nuevo escudo, con las armas de Aragón y Navarra incorporadas.

Por su parte, la Guía de Forasteros de 1869 cambió en su portada el retrato de Isabel II por una alegoría de España como joven esbelta, de actitud serena, acompañada por la Constitución recién aprobada, con el nuevo escudo nacional, ya con corona real y un satisfecho león; como fondo de la imagen se ve un puerto dinámico y próspero con varios barcos bajo un sol resplandeciente. Esta representación no era novedosa, pues había sido utilizada por esta misma guía oficial en 1855, pero ahora se actualizó con 
pequeños retoques para cambiar los cuarteles inferiores del escudo, incluyendo las barras aragonesas, las cadenas navarras y la referencia constitucional ${ }^{20}$. En 1871, la Guía acompañó dicha personificación de la nación de un retrato de "Amadeo I, rey de España » y al año siguiente, además de sumar a la efigie del monarca la de su esposa María Victoria, la alegoría de España se cambió substancialmente: ahora la figura femenina aparecía sentada de lado, junto al león, con corona mural y rama de olivo, sujetando el escudo real de las armas de Castilla y León con el escudete de la cruz de Saboya ; a diferencia del escudo prerrevolucionario, este aparece también rodeado por la leyenda "Amadeo 1‥ Constitución de 1869 ".

En el caso del papel sellado, el nuevo escudo, con corona mural y desprovisto de las columnas, aparece por primera vez en los sellos en seco de 1870 y 1871. El mismo cambia la corona mural por la real e incorpora en el óvalo central la cruz de Saboya, y a veces el nombre del monarca, en los sellos de 1872 y 1873. Las primeras alegorías referidas a España, personificadas en imágenes femeninas (al igual que sucede con las de Castilla y las Indias), se localizan en los sellos de 1854 y 1864 y son precursoras de la matrona que representa a la nación a partir de 1870. La misma aparece en un sello de tinta de color y se refiere a una mujer sedente o de pie, con uno o varios atributos (corona mural y cetro o rama de olivo en 1870-1871; sin corona y con cetro en 1872-1873), no faltando en ninguno de los casos el león a sus pies (que en una ocasión sujeta una esfera con una de sus garras) y un espejo en el que se apoya y que encierra un sello seco con el escudo de las armas nacionales ${ }^{21}$.

Respecto de la bandera, hay que subrayar que, pese a su origen borbónico, no se tomó ninguna medida por parte del Gobierno. El concejal progresista Ángel Fernández de los Ríos abogó, sí, desde el Ayuntamiento de Madrid por una nueva bandera nacional que incorporase el color morado a la rojigualda, por considerar que ningún estandarte podía presentarse en ese momento " como símbolo de la colectividad nacional ». Pero no tuvo éxito. Su propuesta tricolor sólo llegó a utilizarse en cintas, fajas, galones y colgaduras municipales ${ }^{22}$. A efectos prácticos, la rojigualda, que utilizaban todas las armas del ejército desde el decreto de unificación de 1843, siguió teniendo la consideración de bandera nacional y su uso generó amplísimo consenso. Respecto a su carácter oficial, en marzo de 1871 se restableció el mencionado decreto de unificación de banderas militares a todos sus efectos, incluidos los referidos a los " funcionarios de las dependencias del Estado ", con la única variación de sustituir las lises del Borbón por la cruz de Saboya en el óvalo central del escudo ${ }^{23}$.

El imaginario liberal radical asociaba el color morado con la protesta de los comuneros del siglo XVI, cuya bandera contra el absolutismo decían haber vuelto a levantar los revolucionarios de 1868. De ahí que el Sexenio trajese como novedad las primeras propuestas de una bandera que unía el morado al rojo y amarillo. Pero estas enseñas tricolores convivieron sin problemas en aquellos años con la rojigualda, tanto entre monárquicos como entre republicanos -estos más bien como símbolo de su movimiento político-. Por otra parte, si bien la revolución potenció el uso del color morado para simbolizar el triunfo de la libertad, lo cierto es que este no era ajeno a la cultura del reinado isabelino. Aunque el citado decreto sobre unificación de banderas de 1843 obligaba a los cuerpos militares que por privilegio llevasen "el pendón morado de Castilla » a usar en adelante la bandera rojigualda (con el solo añadido de una corbata morada), lo cierto es que estos siguieron utilizando la morada en los desfiles de gala habidos antes y después de la revolución ${ }^{24}$. Dejando de lado el caso de los republicanos, 
el uso del morado por los monárquicos fue recurrente en sus actos callejeros. Los redactores de La Iberia, por ejemplo, llevaron un pendón morado para recibir a Prim en octubre de 1868; en el entierro de este, el director de dicho periódico, Carlos Rubio, envió una corona fúnebre con un lazo morado con la inscripción “ A Juan Prim »; y en la primera manifestación progresista radical, en la que se dieron mueras a Sagasta, los seguidores de Ruiz Zorrilla portaron un retrato de Prim y un estandarte morado en el que se leía "Viva el ministerio radical $»^{25}$.

41 En cuanto a la " marcha nacional » (o " de honor española », como también se decía), el Gobierno tuvo voluntad de sustituir la tradicional Marcha Granadera o Real de la monarquía caída por otra propiamente nacional. Como nuevo himno oficial, una disposición de agosto de 1870 reconoció, interinamente, la Nueva Marcha Real, compuesta por el militar José Squadrani con ocasión de la apertura de las Cortes. Pero Prim creía que la composición carecía de fuerza, y para elegir otra convocó al mes siguiente un concurso, al que se presentaron cerca de 450 composiciones, que al final quedó desierto. En la práctica, el popular Himno de Riego, pese a sus connotaciones revolucionarias, funcionó también como nacional hasta la llegada de Amadeo. Pero una disposición de enero de 1871 repuso la centenaria Marcha Granadera, con el nuevo nombre de Marcha Nacional Española, como música reglamentaria a tocar por ordenanza en los actos oficiales ${ }^{26}$.

42 Terminemos con una referencia a las fiestas nacionales $u$ oficiales. El Dos de Mayo recuperó en Madrid todo su esplendor en 1869, con una serie de actos con alta participación oficial que otorgaron a la fecha rango nacional. El ayuntamiento inauguró ese año la plaza del Dos de Mayo, construida en torno al arco restaurado del desaparecido parque de Monteleón, así como las nuevas calles de Malasaña, Monteleón y Ruiz, que vinieron a sumarse a las ya existentes de Daoiz, Velarde y Dos de Mayo. De esta manera, la capital del Estado tuvo desde entonces dos lugares de memoria para celebrar la " fiesta nacional » : la citada plaza y el obelisco del Prado, que volvió a ser el principal lugar de referencia al año siguiente ${ }^{27}$. Fuera de Madrid, la festividad del Dos de Mayo sólo se celebró con cierto esplendor, que sepamos, en la ciudad de Santander en 1869. En este caso los actos cívicos transcurrieron en la plaza de Velarde, en la que se había levantado el pedestal de la proyectada estatua al héroe de 1808 que le daba nombre, y ese día se celebró también la hazaña militar, de tres años antes, de Méndez Núñez, por encontrarse en la ciudad uno de los héroes del Callao, el comandante de la goleta Prosperidad, que fondeada en el puerto disparó varias veces sus cañones siguiendo el “ programa » oficial consagrado a rendir homenaje a los " defensores de la independencia nacional y de la honra de la patria ${ }^{28}$.

Los intentos de oficializar los aniversarios del 29 de septiembre, fecha del triunfo de la revolución y del destronamiento de los Borbones, y del 6 de junio, día de la promulgación de la Constitución, fracasaron. En 1869, el primer aniversario de la Septembrina fue recordado por los liberales en la prensa y los escenarios de los teatros, pero no se celebró con carácter oficial por estar enfrentados entre sí los dos grandes grupos políticos de la antigua coalición revolucionaria. Los republicanos consideraban que los monárquicos habían traicionado los principios que inspiraron la revolución y las conquistas conseguidas en ella por el pueblo español y, para dificultar más aún la conmemoración conjunta, casi en la misma fecha del triunfo de la Gloriosa un sector de ellos se alzó en armas para proclamar la República Federal ${ }^{29}$. El enfrentamiento entre los propios protagonistas del 68 impidió, pues, utilizar ese día para legitimar la obra 
revolucionaria, haciendo más necesaria que nunca la referencia festiva a 1808. La Constitución monárquico-democrática se promulgó en 1869 con “tres días de fiesta nacional » y con lecturas y celebraciones de la misma por toda España, pero de esta alegría tampoco participaron los republicanos, que pidieron a sus correligionarios y simpatizantes que se abstuviesen de asistir a los festejos. A partir de 1870, tan sólo algunos gobernadores monárquicos hicieron algún homenaje oficial a la Constitución ${ }^{30}$. Si los partidos revolucionarios fueron incapaces de celebrar dos fechas que entrarían en los anales del liberalismo español, ni que decir tiene que los grupos conservadores y católicos, desde alfonsinos a carlistas, rechazaron tajantemente lo que esos días representaban, llegando los segundos a alzarse en armas, en el verano de 1869, a favor de la unidad católica y contra la libertad religiosa reconocida por la Constitución.

\section{Lugares de memoria}

El Panteón Nacional fue el más elocuente de los monumentos representativos de la identidad colectiva que intentó crear el Sexenio. Un Real Decreto de 1869 ordenó dar cumplimiento a la Ley que en 1837 había dispuesto la conversión de la iglesia de San Francisco el Grande de Madrid en lugar privilegiado en el que reposarían los restos de los españoles ilustres. El Panteón se inauguró solemnemente el 20 de junio de 1869 con una gran fiesta cívica. Una procesión de catorce carrozas trasladó los restos de otros tantos hombres ilustres (Gravina, Calderón, Lanuza, Ercilla, Gonzalo de Córdoba, Juan de Mena...), más un “ carro triunfal de España » que abría la comitiva (con los escudos de todas las provincias, las columnas de Hércules, el león y la bandera nacional), y un " carro de la Fama ", que la cerraba, con las banderas de todas las naciones de Europa ${ }^{31}$.

Pero el Panteón se enfrentó pronto con problemas derivados de la resistencia de las autoridades locales a la entrega de los restos de sus respectivos " hijos predilectos ». Y entró en decadencia a partir de 1874, siendo desmantelado en los tres primeros lustros de la Restauración y la iglesia devuelta al culto en 1889.

En cuanto a los museos, durante el Sexenio revolucionario se produjeron dos hechos significativos. El primero fue la inauguración, por Amadeo I, en julio de 1871, del Museo Arqueológico Nacional, que recogía y exhibía objetos de los “tiempos primitivos » e incluía, entre su colección medieval, una sala árabe ${ }^{32}$. El segundo fue la supresión del museo de pinturas del exconvento de la Trinidad, cuyos fondos fueron cedidos al hasta ahora Real Museo del Prado, rebautizado en 1872 como Museo Nacional de Pintura y Escultura.

Un aspecto importante en la construcción simbólica y el poder material del nuevo Estado surgido de la revolución septembrina fue el tratamiento otorgado al hasta entonces llamado Patrimonio Real. Este patrimonio fue extinguido por ley de 18 de diciembre de 1869 y pasó a ser propiedad del Estado y administrado por el Ministerio de Hacienda. Los bienes que lo constituían recibirían tres posibles destinos : como norma general, serían enajenados ; en casos excepcionales (palacios de Oriente, de Aranjuez, El Pardo, San Ildefonso, Palma...), seguirían destinados al uso y servicio de la casa real ; y habría edificios, monumentos, museos y jardines emblemáticos que, por su valor histórico o artístico o su servicio al Estado, se conservarían de forma también excepcional, convertidos en patrimonio nacional ${ }^{33}$.

El Retiro fue un ejemplo destacado de cesión, decretada ya por el Gobierno Provisional en el otoño del 68, al Ayuntamiento de Madrid, que procedió a derribar 
inmediatamente su tapia para que " pudiera ser disfrutado sin restricciones por todos los vecinos de la capital ", " no sólo como medida higiénica y de recreo, sino como elemento de instrucción y de moralidad $\aleph^{34}$. Un ejemplo distinto fue el de la Alhambra de Granada, declarada monumento nacional histórico-artístico en febrero de 1870 ; de su vigilancia e inspección se hizo cargo la Comisión Provincial de Monumentos de Granada, con Rafael Contreras como su primer director y conservador ${ }^{35}$.

49 En Madrid no se llegaron a construir, durante el Sexenio, nuevos monumentos conmemorativos, pero se pusieron en la vía pública estatuas que se hallaban en museos o almacenes. La primera, el grupo escultórico de Daoiz y Velarde, de Antonio Solá, al que se añadió una inscripción de Espronceda sobre la falta de patriotismo del “ ingrato " rey Fernando VII. La segunda, la estatua de Mendizábal, de José Grajera, realizada en el Bienio, colocada ahora en la Plaza llamada significativamente del Progreso e inaugurada el día de la promulgación de la Constitución. Y una tercera a Murillo, gemela de otra sevillana e inaugurada por Amadeo I junto al Museo del Prado. En 1872 se plantaron también en su ubicación actual los leones del Congreso, fundidos, como dice su leyenda, con el metal de los cañones capturados al enemigo durante la guerra marroquí de $1859-1860^{36}$.

Del resto de la actividad monumental debe resaltarse la confluencia de la exaltación de la idea nacional con la de la revolución liberal. Pocas fueron las realizaciones, pero muchos los proyectos o iniciativas que no llegaron a término. En cuanto a las primeras, se puede mencionar la estatua de fray Luis de León, cuya idea procedía de la época anterior pero que se inauguró en 1869 , sin duda valorando el carácter de víctima inquisitorial del personaje homenajeado ${ }^{37}$. En tres monumentos al menos se conectó la Guerra de la Independencia con la nueva situación revolucionaria : el de Arapiles, en Salamanca, que a la vez era un homenaje a la libertad restaurada por la Septembrina; el de Velarde, en Santander, ya mencionado, y que no llegó a completarse hasta 1880 ; y el mausoleo de Álvarez de Castro, en Gerona, cuya primera piedra puso el rey Amadeo I ${ }^{38}$. Otros cuatro monumentos que llegaron a inaugurarse, a veces sin completar, homenajeaban a los "mártires " y defensores de la libertad: a los "Coloraos », en Almería, ejecutados en 1824 (inaugurado en 1870); a los fusilados en Palencia en 1867 ( 1869 ; incompleto, y desaparecido con la Restauración) ; a los defensores de Bilbao en 1836 (1870); y al propio Espartero en Logroño (1872, en presencia del propio Pacificador, e incompleto también) ${ }^{39}$.

51 En cuanto a los monumentos que no pasaron de ser mera propuesta, su denominador común es la conexión entre la lucha por la independencia nacional y la libertad política : al Empecinado en Alcalá de Henares, al 7 de julio de 1822 en Madrid, a la resistencia de Zaragoza, al Convenio de Vergara ${ }^{40}$, a la propia Revolución del 68, a Prim tras su muerte (en Barcelona y Madrid) ${ }^{41}$, a Riego en Cabezas de San Juan, a las víctimas de El Carral (1846), a los fusilados de 1848 en Madrid $^{42}$... Un caso de especial significado fue el del Quemadero de la Cruz, también en la capital del Estado: descubierta, al excavarse la plaza del Dos de Mayo en Madrid, una zona ennegrecida, se supuso que allí se realizaban las hogueras inquisitoriales y se propuso a las Cortes erigir en aquel lugar un monumento a la libertad de cultos, para "transmitir a las generaciones venideras la execración que merece el fanatismo religioso». No llegó ni a ser aprobado por la cámara, pero sí se dio el nombre de Carranza (por el arzobispo) a la calle donde estaba situado $^{43}$. 

tales como los títulos nobiliarios concedidos por Amadeo I : Príncipe de Vergara, a Espartero ; Conde de Santa Engracia, al defensor de la puerta de dicho nombre durante los sitios de Zaragoza de 1808; Marqués de Cenia, por una acción bélica contra los carlistas en 1840 ; o Conde de Serrallo, por otra similar en la Guerra de África. regimientos, navíos de guerra, teatros o incluso ciudades. El más emblemático, desde el punto de vista de la construcción nacional, fue la sustitución del nombre de la villa valenciana de Murviedro por Sagunto, decisión que se justificó con el fin de "perpetuar un hecho heroico » admirado por “ los amantes de las glorias patrias » ${ }^{44}$. En cuanto a los rótulos de las calles, los ayuntamientos democráticos tendieron a sustituir los relativos a la dinastía caída y a veces los religiosos por otros alusivos a los mártires de la libertad o a los hitos y glorias nacionales. El de Madrid, por ejemplo, bautizó algunas calles y plazas con los nombres de Covadonga, Bravo, Maldonado, Prim, Dos de Mayo o 29 de Septiembre ${ }^{45}$. Secuencia que subrayaba la continuidad de la nación desde la segunda década del siglo VIII hasta el último tercio del XIX, pasando por fechas como $1521 \mathrm{o}$ 1808 (algo que quedó más explícito que nunca en el escudo que figuró en el Boletín oficial del Ayuntamiento de Madrid de 1869 ; ver figura ${ }^{46}$ ).

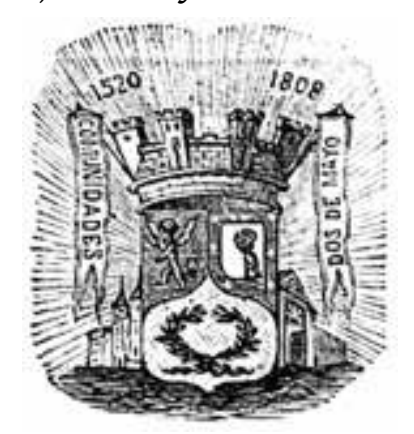

Figura 1

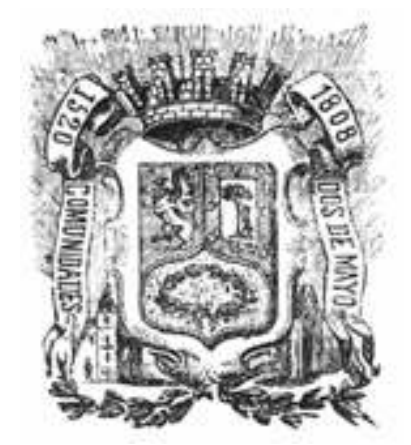

Figura 2

Un último proyecto que merece especial mención, por su ambición y significado, fue el propuesto por Fernández de los Ríos para la remodelación del centro de Madrid. Su objetivo era, obviamente, convertir la ciudad en modélica capital de la nación. Para ello se crearía una Plaza de la Independencia, en torno a la Puerta de Alcalá, en la que confluirían ocho calles alusivas a las glorias nacionales, con los nombres de Sagunto, Numancia, Covadonga, Granada, Padilla, Bravo, Maldonado y Lanuza. Más simbólica aún, si cabe, era una calle Nacional que uniría, en línea recta, el edificio de las Cortes con el Panteón. Como es sabido, de todo este proyecto únicamente se llevó a cabo la plaza 
de la Independencia, aunque sin las ocho calles previstas a su alrededor. Retomando un proyecto municipal de 1859, sí se llegó a ejecutar, en cambio, el Viaducto de hierro sobre la calle Segovia, iniciado con los derribos para la cimentación en 1868 y la colocación de sus primeras piezas metálicas en 1872 e inaugurado en 1874, expresión menor del ideal modernizador que encarnaba con mucha más fuerza la nonata calle Nacional ${ }^{47}$.

\section{Conclusiones} Porque ese ente natural e histórico al que España era, según lo definían, fatalmente liberal y democrático. España no estaba constituida por la monarquía ni la religión y, como comunidad soberana basada en la libertad individual y el sufragio universal, podía decidir libremente ser monárquica o republicana. Las Cortes constituyentes optaron por la monarquía, aceptando al rey no como copartícipe de la soberanía sino como símbolo de la unidad nacional. Pero mantuvieron al país veintiséis meses sin monarca y, al abdicar Amadeo, optaron sin grandes vacilaciones por la República. En cuanto al catolicismo, pese a su fuerte arraigo social, tampoco era elemento irrenunciable de la identidad española, ni siquiera para los monárquicos liberales. Los ciudadanos españoles eran libres de escoger su fe, como lo eran de decidir su forma de régimen y de designar al portador de la corona.

En cuanto a los símbolos, los más consolidados fueron los de procedencia más antigua : bandera e himno, ambos del siglo XVIII. Y los monumentos, según hemos visto, tuvieron como característica común la confluencia entre el ideal nacionalizador y la exaltación de la revolución liberal. 

continuación la República, que mantuvo vivo, desde luego, ese proyecto. Pero esta acabó derrumbándose en un plazo muy breve, enfrentada con otros múltiples problemas, que requieren sin duda un artículo aparte.

\section{NOTAS}

1. Sobre las visiones liberal y católica de la nación : José ÁLVAREZ JUNCO, Mater Dolorosa. La idea de España en el siglo XIX, Madrid, Taurus, 2001.

2. José ÁLVAREZ JUNCO, La Comuna en España, Madrid, Siglo XXI, 1971.

3. El Nuevo Pelayo, 4-VIII-1872.

4. Nombres similares en algunos de los principales cafés de Barcelona : Café de España, Nacional, Ibérico, Español o Pelayo ; Cayetano CORNET Y MAS, Guía de Barcelona, Barcelona, 1876, p. 13.

5. Sobre nacionalismo progresista, $\mathrm{M}^{\mathrm{a}}$ Cruz ROMEO MATEO, “ Memoria y política en el liberalismo progresista : la nación de la libertad », en Javier MORENO LUZÓN (ed.), Izquierdas y nacionalismos en la España contemporánea, Madrid, FPI, 2011, p. 11-39.

6. Sobre los dos proyectos liberales del Sexenio : Gregorio de la FUENTE MONGE, “Monarquía y República en la España revolucionaria (1868-73) », en Ángeles LARIO (ed.), Monarquía y República en la España contemporánea, Madrid, Bib. Nueva, 2007, p. 205-229.

7. Jamases de Prim en DSCC, 22-II-1869 ; su anterior alocución a los zaragozanos, que acabó con un “ ¡Abajo, para siempre, la dinastía de los Borbones! », en La Iberia, 9-X-1868. Otras citas y lo que sigue sobre la fiesta revolucionaria en Gregorio de la FUENTE MONGE, Los revolucionarios de 1868, Madrid, Pons, 2000, p. 92-107 ; cf. Gregorio de la FUENTE MONGE y Rafael SERRANO GARCÍA, La revolución gloriosa. Un ensayo de regeneración nacional, Madrid, Bib. Nueva, 2005, p. 46-48 y 51-52.

8. Gregorio de la FUENTE MONGE, "El teatro republicano de la Gloriosa ", Ayer, nº 72, 2008, p. 92-96.

9. José ÁLVAREZ JUNCO, Mater Dolorosa..., p. 219-226 y 431 ; José ÁLVAREZ JUNCO y Gregorio de la FUENTE MONGE, El relato nacional. Historia de la historia de España, Barcelona, Taurus, 2017, 
p. 215-225; Gregorio de la FUENTE MONGE, "El republicanismo de 1868 y la mitología nacionalista liberal », en Javier MORENO LUZÓN y Fernando DEL REY (eds.), Pueblo y Nación, Madrid, Taurus, 2013, p. 249-253.

10. Para lo que sigue, Gregorio de la FUENTE MONGE, “Monarquía y República... », p. 208-217 ; y Joaquín VARELA, “La monarquía en las Cortes y en la Constitución de 1869 ", Historia Constitucional, $\mathrm{n}^{\mathrm{0}}$ 7, 2006.

11. Sobre estas medidas anticlericales : José ANDRÉS GALLEGO, “La legislación religiosa en la revolución española de 1868 ", Ius Canonicum, no 33, 1977, p. 257-301; Vicente CÁRCEL ORTÍ, Iglesia y revolución en España, 1868-1874, Pamplona, EUNSA, 1979; Antonio MOLINER PRADA, “Anticlericalismo y revolución liberal (1833-1874)», en Emilio LA PARRA LÓPEZ y Manuel SUÁREZ CORTINA (eds.), El anticlericalismo español contemporáneo, Madrid, B. Nueva, 1998, p. 104-116; y Gregorio de la FUENTE MONGE, “El enfrentamiento entre clericales y revolucionarios en torno a 1869 ", Ayer, no 44, 2001, p. 127-136.

12. Albino FEIJÓo GÓMEZ, Quintas y protesta social en el siglo XIX, Madrid, Ministerio de Defensa, 1996. Cf. Gregorio de la FUENTE MONGE y Rafael SERRANO GARCÍA, La revolución gloriosa..., p. $178-184$.

13. Gaceta de Madrid, 15 y 22-X-1868 (decretos Fomento 14 y 21 octubre) ; Antonio VIÑAO FRAGO, “La educación en el Sexenio ", Anales de Pedagogía, nº 3, 1985, p. 87-102 ; Mercedes SUÁREZ PAZOS, A educación en España durante o Sexenio Revolucionario, Universidad de Vigo, 2002 ; y Rafael SERRANO GARCÍA, “La educación y la cultura ", en Ana MARTÍNEZ RUS y Raquel SÁNCHEZ GARCÍA (eds.), Las dos repúblicas en España, Madrid, FPI, 2018, p. 239-258.

14. Informe en Boletín de la Real Academia de la Historia, 1884, t. 4, p. 186-191. Reproducido, junto a otras fuentes aquí utilizadas, en Gregorio de la FUENTE MONGE y Rafael SERRANO GARCÍA, La revolución gloriosa..., cap. 7. Con carácter general, sobre símbolos y lugares de memoria, Carlos SERRANO, El nacimiento de Carmen. Símbolos, mitos y nación, Madrid, Taurus, 1999; Símbolos de España, Madrid, CEPC, 1999 ; Javier MORENO LUZÓN y Xosé M. NÚÑEZ SEIXAS, Los colores de la patria. Símbolos nacionales en la España contemporánea, Madrid, Tecnos, 2017, cap. 1 ; y Marie-Angèle OROBON, “La carne de la política : ruptura democrática y simbología », Ayer, no 112, 2018, p. 73-98.

15. Sobre las monedas, Miguel MARTORELL, Historia de la peseta, Barcelona, Planeta, 2001 ; José M ª de FRANCISCO OLMOS, “La peseta : nueva unidad monetaria y medio de propaganda política (1868-1936) », en VII Jornadas sobre Documentación Contemporánea, Madrid, 2008, p. 121-153 ; y José Miguel SANTACREU SOLER, “La revolución monetaria española de 1868 ", Anales de Historia Contemporánea, $\mathrm{n}^{\mathrm{0}}$ 10, 1994, p. 511-523.

16. Se debate si quien figura en el billete de 100 escudos es el portugués Vasco de Gama y no Cortés. Véase Teresa TORTELLA CASARES, “El billete español en la Edad Contemporánea : mucho más que un medio de pago ", en VII Jornadas..., p. 331-368 (Cortés, p. 338) ; y Los billetes del Banco de España, Madrid, Banco de España, 1974 (Vasco de Gama, p. 81).

17. En 1868 se rompió la tradición, iniciada en 1856, de reproducir en los billetes de este banco alegorías de España como mujer joven que en su versión más completa portaba casco y lanza y estaba acompañada del león y el escudo. La más novedosa fue la del billete de 100 escudos de marzo de 1868, primero de los fabricados en los talleres de este banco, en el que la mujer que representa a España porta corona mural y bastón, se apoya en el león y tiene a sus pies un escudo con corona real.

18. Cfr. Catálogo unificado Edifil de sellos de España, Madrid, 2014 ; y Guillermo NAVARRO OLTRA, “Introducción ", en IDEM (ed.), Autorretratos del Estado, Universidad de Cantabria, 2015, t. I, p. 13-17.

19. Gregorio de la FUENTE MONGE y Rafael SERRANO GARCÍA, La revolución Gloriosa de 1868 en Palencia, Palencia, ITTM, 2018, p. 70-75 ; Marie-Angèle OROBON, “Alegorías y heroínas : Usos políticos de la imagen femenina en el Sexenio democrático", en $\mathrm{M}^{\text {a }}$ Concepción MARCos del 
OLMO y Rafael SERRANO GARCÍA (eds.), Mujer y política en la España contemporánea, Universidad de Valladolid, 2012, p. 20-21; y Mario RUIZ ENCINAR, "Aproximación a los emblemas revolucionarios en La Rioja del siglo XIX », Boletín de la Asociación Riojana de Genealogía y Heráldica, no 4, 2012, p. 91-93.

20. Las imágenes de 1855 y 1869, respectivamente, en Carlos REYERO, Monarquía y Romanticismo. El hechizo de la imagen regia, Madrid, Siglo XXI, 2015, fig. 8 (p. 41-42), y Gregorio de la FUENTE MONGE y Rafael SERRANO GARCÍA, La revolución gloriosa..., p. 328.

21. Natalia PÉREZ-AINSUA MÉNDEZ, De sellos, heráldica y alegorías. El papel sellado en España, Universidad de Sevilla, 2014.

22. Cintas o galones tricolores, p. ej., al inaugurarse estatua de Mendizábal (Gaceta de Madrid, 8VI-1869) y en nuevos uniformes de guardias madrileños (La Época, 3-V-1871). Cf. Ángel FERNÁNDEZ DE LOS RÍOS, Guía de Madrid, Madrid, 1876, p. 249-250 y 465-467. Esta tricolor fue también utilizada por monárquicos de Barcelona (v. Pere ANGUERA, Les quatre barres, Barcelona, Dalmau, 2010, p. 38).

23. Recopilación de las Reales Órdenes y Circulares de interés general para la Guardia Civil expedidas en todo el año de 1871, Madrid, 1871, p. 55-58 y 89-90.

24. Por ejemplo, en la última festividad del Dos de Mayo anterior a la revolución el regimiento Inmemorial del Rey desfiló con la bandera morada regalada por la reina tras la campaña de África (La Correspondencia de España, 2-V-1868) ; uso de esta bandera por los cuerpos “privilegiados y de casa real », en El Averiguador, 15-VII-1872, p. 197 ; igualmente, Ángel FERNÁNDEZ DE LOS RÍOS, Guía..., p. 466.

25. La Correspondencia de España, 7-X-1868 ; La Nación, 3-I-1871; La Época, 4-X-1871; cfr. El Imparcial, 15-VI-1872. El Ayuntamiento de Madrid también utilizó un fajín morado con las armas de la villa (La Discusión, 6-III-1872).

26. Sobre el himno, véase Himno nacional de España. Origen y evolución, Madrid, Ministerio de Defensa, 2012; y María NAGORE FERRER, "Historia de un fracaso: el "himno nacional” en la España del siglo XIX », Arbor, nº 751, 2011, p. 827-845.

27. Boletín Oficial del Ayuntamiento, Madrid, 3-V-1869 ; Ángel FERNÁNDEZ DE LOS RÍOS, Guía..., p. 174-176; Christian DEMANGE, El Dos de Mayo. Mito y fiesta nacional, Madrid, Pons, 2004, p. 183-194.

28. Boletín de Comercio, 3-V-1869.

29. Por ejemplo, La Iberia, 29 y 30-IX-1869 ; La Discusión, 29-IX-1870.

30. El Imparcial, 26-V-1869 (tres días de fiesta); La Iberia, 10 y 12-VI-1869 (críticas a clero y republicanos por no participar en la “ fiesta nacional ») ; La Discusión, 1-VI-1869 (club republicano Antón Martín contra celebración) ; La Igualdad, 6-VI-1869 (única Constitución “ popular », la de 1812).

31. Carolyn BOYD, “ Un lugar de memoria olvidado : El Panteón de Hombres Ilustres en Madrid », Historia y Política, no 12, 2004, p. 15-39; Ángel FERNÁNDEZ de los RÍOS, Guía..., p. 442-450. El Panteón debía haberse inaugurado el 6 de junio, día de la proclamación de la Constitución ; cf. DSCC, 1-VI-1869, p. 2493 ; Gaceta de Madrid, 2 y 20-VI-1869. Sobre arte y memoria, incluida Exposición Nacional de 1871, Javier HERNANDO CARRASCO, Las Bellas Artes y la revolución de 1868, Universidad de Oviedo, 1987 ; e ID., “ Madrid 1868 : la fiesta revolucionaria », Ayeres, vol. 2, 끈 3, 1991, p. 25-28 ; para pintura, Tomás PÉREZ VEJO, España imaginada, Madrid, Galaxia Gutenberg, 2015, p. 169-201.

32. Ventura RUIZ AGUILERA, Discurso... inauguración del Museo Arqueológico Nacional, Madrid, 1871 ; Juan de Dios de la RADA y Juan de MALIBRÁN, Memoria... Museo Arqueológico Nacional, Madrid, Colegio Nacional de Sordo-Mudos, 1871 ; Ángel FERNÁNDEZ de los RÍOS, Guía..., p. 450-459; e Inmaculada ZARAGOZA GARCÍA et al, "El MAN durante el Sexenio Revolucionario ", Boletín del Museo Arqueológico Nacional, t. 4, nº 2, 1986, p. 189-195. 
33. Gaceta de Madrid, 15-X-1868 (creación del Consejo del Patrimonio que fue de la Corona), 19XII-1868 (nueva Dirección general) y 19-XII-1869 (extinción).

34. Sobre el Retiro, Gaceta de Madrid, 7-XI-1868, y Ángel FERNÁNDEZ de los Ríos, Guía..., p. 366-370.

35. Isabel ORDIERES DÍEZ, Historia de la restauración monumental en España (1835-1936), Madrid, Ministerio de Cultura, 1995, p. 168. Síntesis sobre la historia del Patrimonio del Estado : Pedro $\mathrm{M}^{\text {a }}$ BELMONTE MEDINA, "Historia jurídica del Patrimonio de la Corona durante el Sexenio Revolucionario », Derecho y Opinión, no 7, 1999, p.67-78; y María Paz CABELlO CARO, “Del Patrimonio de la Corona hasta el actual Patrimonio Nacional (1819-1950) », Patrimonio Cultural y Derecho, no 18, 2014, p. 249-288.

36. Salvo indicación contraria, información sobre monumentos procede de Carlos REYERO, La escultura conmemorativa en España, Madrid, Cátedra, 1999 ; José RINCÓN LAZCANO, Historia de los monumentos de la villa de Madrid, Madrid, 1909 (incluye los proyectados) ; o Pierre GÉAL, “ Un siglo de monumentos a la Guerra de la Independencia ", en VV.AA., Sombras de mayo, Madrid, Casa de Velázquez, 2007, p. 153-155. Sobre los de Madrid, también Ángel FERNÁNDEZ de los RíoS, Guía... ; Gaceta de Madrid, 8-VI-1869 ; y M ${ }^{\text {a }}$ Socorro SALVADOR PRIETO, "Precisiones a un monumento escultórico madrileño desaparecido: Mendizábal », Anales de la Historia del Arte, no 4, 1994, pp. 505-511.

37. Boletín-Revista de la Universidad de Madrid, 10-V-1869, p. 490-493.

38. La Nación, 21-IX-1871; Stéphane MICHONNEAU, "Gerona, baluarte de España. La conmemoración de los sitios de Gerona en los siglos XIX y XX», Historia y Política, n⿳ำ 14, 2005, p. 200-201; La Ilustración Española y Americana, 15-V-1880 (inauguraciones Velarde y Álvarez).

39. Fernando MARTÍNEZ LÓPEZ, "Los Coloraos » : el 24 de agosto en la historia de Almería, Almería, IEA, 1987 ; Gregorio de la FUENTE MONGE y Rafael SERRANO GARCÍA, La revolución Gloriosa de 1868 en Palencia..., p. 135-136; Carlos REYERO, Monarquía..., p. 50 (cementerio Mallona, Bilbao); La Nación, 3-III-1872 (Espartero, primera piedra); Adrian SHUBERT, Espartero, el Pacificador, Barcelona, Galaxia Gutenberg, 2018, p. 543. Cfr. DSCC, 1869, p. 2409 (Bilbao).

40. Gaceta de Madrid, 13-XI-1868 ; La Correspondencia de España, 6-III-1869. Antecedentes : Adrian SHUBERT, Espartero..., p. 542.

41. La Crónica de Cataluña, 7-I-1871 ; La Convicción, 24-I-1871 ; La Correspondencia de España, 8III-1872 ; y Stéphane MICHONNEAU, Barcelona : memòria i identitat, Vic, Eumo, 2001, p. 73-75 (71-72 para monumento proyectado a las Cortes del 69).

42. DSCC, 1869 , p. 5491, 3623 y 4028.

43. DSCC, 1869, Ap. $7^{\circ}$ al no 73 (proposición de ley). Cf. Ángel FERNÁNDEZ de los RÍOS, Guía..., p. 175.

44. Gaceta de Madrid, 4-XII-1868 ; 14-X-1868 para fragata Sagunto (antes Príncipe de Asturias) y pueblo de Nava de la Libertad (antes del Rey), en Valladolid.

45. Gregorio de la FUENTE MONGE, Los revolucionarios..., p. 102. Cfr. Ángel FERNÁNDEZ de los RÍOS, Guía...

46. Versión de 1872 en figura 2.

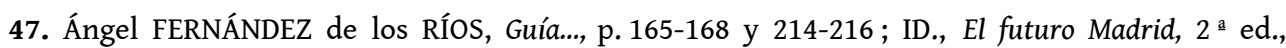
Madrid, 1868, p. 140-141; y La Ilustración Española y Americana, 16-III-1872 (primera pieza de hierro). Memoria del Viaducto (1859), en Revista de Obras Públicas, ํo18, 1861, p. 217-224. 


\section{RESÚMENES}

La fase pre-republicana del Sexenio, es decir, el período 1868-72, supuso un importante impulso de construcción nacional. Pese a sus discrepancias internas, las élites revolucionarias compartían unos acuerdos básicos : que existía una identidad española muy arraigada en la historia ; que su esencia era liberal; que la revolución había sido producto de la voluntad nacional; y que construir una España liberal y moderna supondría reintegrarla entre las grandes potencias europeas. De ahí sus esfuerzos por construir los símbolos nacionales (bandera, escudo, himno, fiestas, monedas, sellos de correos, monumentos y lugares de memoria). Pero este proyecto chocó con las divisiones internas y la inestabilidad política del período, la propia debilidad del Estado que se construía a la vez que la nación y, sobre todo, la confusión entre idea nacional y proyecto liberal, que excluía a la España católico-conservadora.

La phase pré-républicaine du Sexenio, c'est-à-dire la période 1868-1872, attesta d'un élan important de la construction nationale. En dépit de leurs divergences internes, les élites révolutionnaires partageaient des accords fondamentaux: il existait une identité espagnole profondément enracinée dans l'Histoire: son essence était libérale, la révolution avait été le produit de la volonté nationale, et pour conclure, construire une Espagne libérale et moderne contribuerait à lui rendre son rang parmi les grandes puissances européennes. D'où leurs efforts pour construire des symboles nationaux (drapeau, bouclier, hymne, fêtes, pièces de monnaie, timbres-poste, monuments et lieux de mémoire). Mais ce projet s'est heurté aux divisions internes et à l'instabilité politique de l'époque, à la faiblesse même de l'État qui se construisait en même temps que la nation et, surtout, à la confusion entre l'idée nationale et le projet libéral, qui excluait l'Espagne catholique-conservatrice.

The pre-Republican years of the Revolutionary Sexenium (i. e., 1868-1872), witnessed a strong push for nation-building in Spain. In spite of their internal divisions, revolutionary élites shared several basic agreements: they all believed in a centuries-old Spanish identity; they agreed on its Liberal essence; they claimed that the 1868 revolution had been a product of the national will; and they were certain that building a modern and progressive Spain would locate the country among the major European powers. This is why so important efforts were made to build and strengthen national symbols (flag, anthem, festivities, coins, stamps, monuments and lieux de mémoire). But these efforts had to confront internal divisions, political instability, weakness of the political structure that was being built parallel to the national identity and, above all, the close intermix between the national and the liberal project, something which excluded Catholicconservative Spaniards.

\section{ÍNDICE}

Keywords: Revolution of 1868, Sexenio Democrático, liberalism, Spanish nationalism, places of memory, national symbols and myths.

Mots-clés: Révolution de 1868, Sexenio Démocratique, libéralisme, nationalisme espagnol, lieux de mémoire, symboles et mythes nationaux.

Palabras claves: Revolución de 1868, Sexenio Democrático, liberalismo, nacionalismo español, lugares de memoria, símbolos y mitos nacionales. 
AUTORES

JOSÉ ÁLVAREZ JUNCO

Universidad Complutense de Madrid

GREGORIO DE LA FUENTE MONGE

Universidad Complutense de Madrid 